\title{
Financial Literacy Initiative at a Liberal Arts College: What Student's Want (\& Need)!
}

\author{
Michelle Hagadorn \\ Roanoke College \\ Marissa Lahousse \\ Virginia Tech
}

The college years are an important time in the life of young adults as they are faced for the first time with important personal financial decisions. Since they have reached the legal age to enter into binding contracts, these decisions have potential long-term negative consequences. Students are graduating with large amounts of debt and starting out in their careers with very limited spending which impacts their ability to obtain car or home loans ("Financial Literacy," 2014). Education institutions play an important role in developing financially literate citizens. This paper discusses the need and interest in a financial literacy program at a small liberal arts college in Virginia.

Keywords: Financial Literacy, College Students

\section{INTRODUCTION}

The college years are an important time in the life of young adults as they gain increased independence and responsibility. In addition, to managing their schedules, student are often faced for the first time with important personal financial decisions. For example many students encounter real-world debt related issues, such as credit cards or students loan. Since they have reached the legal age to enter into these binding contracts, these financial decisions can have potential long-term negative consequences such as damage to their credit history. According to Friedman (Friedman, 2018) in a recent Forbes article, student loan debt is estimated at $\$ 1.52$ trillion which is a $\$ 29$ billion dollar increase just in the last quarter. The average debt for students graduating in 2016 was $\$ 37,172$, with student loan debt accounting for the second largest source of consumer debt only behind mortgages. The current average default/delinquency rate is $10.9 \%$ which is over $\$ 60$ billion. Students graduating with these large amounts of debt and starting out in their careers are very limited in their spending and their ability to obtain car or home loans which fuels the economy ("Financial Literacy," 2014). According to Ergun (2017) "governments and some organizations have realized that financially knowledgeable citizens are essential for a nation's wellbeing". Therefore few argue about the importance of financially literate citizens with educational institutions having an important role to play. The purpose of this paper was to evaluate the need and interest in a financial literacy program at a small liberal arts college in Virginia. In the next section, a 
brief review of the literature will focus on the timing of education delivery, various educational models and the topics of interest reported by students.

\section{LITERATURE REVIEW}

Research ("Survey," 2018) supports the idea that financial literacy programs should not just focus on students nearing graduation, but start right from the beginning of a student's college career to potentially prevent future problems. The top reason students drop out of college is due to financial issues and the need to work ("Survey," 2018). According to a recent survey, Money Matters on Campus (Moore, 2004), many students starting college are already exhibiting risky behavior with almost $30 \%$ of all students entering college having a credit card and most having more than one. The concerning issue is that around $25 \%$ of these students already have an outstanding balance greater than $\$ 1,000$ and $5 \%$ with a balance greater than $\$ 5,000$. These early warning signs of financially risky behavior at the start of the college experience increases the stress to successfully complete a degree. According to Nguyen (2012), nearly $30 \%$ of college students who took out loans dropped out of school according to a report by Education Sector and these dropouts are four times more likely to default on their loans than students who graduate.

Unfortunately students are coming to college unprepared to make the important financial decisions they will encounter. This may not come as a surprise to some as only 17 states require a high school course in personal finance ("Survey," 2018). As noted in a 2009 research study by the National Endowment for Financial Education, over $60 \%$ of college students surveyed indicated that they had never taken a personal finance course while in high school, underscoring the need for more financial education while in college.

Research has documented ("Federal," n.d.; McCormick, 2009) five specific approaches to financial education: 1) interactive online programs, 2) classroom-based programs, 3) game-based education, 4) event-based programs, and 5) individual counseling. Interactive online programs are popular at larger institutions since they are cost efficient and allow students to learn at their own pace on their own schedule. The main downside is the lack of human interaction, which can be offset by incorporating multimedia videos to increase student engagement ("Financial," 2014). Another option is classroombased programs, such as, semester length courses or guest lectures in certain classes. Again this approach is relatively low cost since large numbers of students can be reached at one time; however the ability to tailor the education and counseling to individuals within the class is somewhat limited. Also the use of financial games, which can include simulations, contests, board games, card games, or electronic games, increases the "fun factor" which can create a collaborative learning environment. Special events are the fourth method often used to help programs gain visibility on campus, create buy-in and deliver program content. The final approach is individual counseling, which can be provided by professional staff members or student peers in various formats, such as face-to-face, over the phone or web-based (Grable, Law, \& Kaus, 2012). The counseling services provided can range of services from providing assistance when dealing with financial problems to more preventive assistance, such as, goal setting, establishing a budget which can include managing cash and credit.

According to research by the Coalition of Higher Education Assistance Organizations (COHEAO) there is no perfect operational model for a campus financial literacy program which are managed by a wide variety of campus departments most often within academic affairs or student affairs (Grable, Law, \& Kaus, 2012). However several studies (Goetz, Cude, Nielsen, Chatterjee, \& Mimura, 2011; Lyons, 2004) have found that students are most interested in the online delivery method, followed by workshops and then counseling centers. Goetz et al. (2011) suggests that based on the strong interest in various educational formats, higher educational institutions should consider a multipronged approach with research indicating that the methods are complementary in nature.

Many studies have found that college students are interested in financial education (Lyons, 2004; Lyons \& Hunt, 2004; Moore, 2004) which is encouraging. A study by U.S. Bank (2017) of 1,628 undergraduate college and high school students ages 18-30 was conducted online followed by 21 more detailed interviews with individual students. According to this research students reported interest in the 
following topics: saving money (51\%); investing money (43\%); understanding credit (40\%); and debt and money management (28\%). So the literature supports starting early in the educational career of a college student by offering a multi-pronged approach to instruction. Next the survey administered at the focus institution for this paper is discussed.

\section{SURVEY RESULTS}

Students on one campus of a small liberal arts college in southwestern Virginia were surveyed to better understand their level of financial literacy, interest in a program and topics most important to them. A capstone course in the intellectual inquiry curriculum (INQ) was selected as the population to complete the survey. The INQ program consists of seven classes, which are required as part of the general education curriculum. The Contemporary Issues capstone class varies dramatically by topic, however still encompasses the importance of empowerment for individuals to solve problems with complexity, diversity, intellect, and creativity. This class was chosen to complete the survey because it is a capstone requirement in the general education sequence that encompasses all majors and minors, and is typically taken by upper level students. In addition, since most of these students were nearing the end of their college careers we felt they would have a better perspective on the types of financial issues and decisions faced by college students. The survey questions can be found in Appendix 1.

There were 376 students enrolled in this course during the 2017-2018 academic year. The survey was completed by 198 students in total of which 182 students (92\%) were seniors and the remaining $8 \%$ were juniors. Students were asked about their perceived level of financial intellect, as well as, a few detailed questions to test just that. When asked about their current financial situation, 34\% of students stated they were just barely keeping up while $66 \%$ claimed to be financially stable. When students graded themselves on managing their money, the result was very honest but also alarming. Over half the students graded themselves with a D in managing money while less than $5 \%$ of students graded themselves A or B.

Students were asked to rate their interest in learning about financial literacy on a 0 to 5 scale, with 5 indicating high interest. The mean score was 3.97. More importantly, we asked the students how important it was to them that Roanoke College offer opportunities to learn about personal finances, which resulted in a mean of 4.39 out of 5. In addition students selected topics they were interested in learning more about with managing money being the topic choice, followed by investing and budgeting. The responses on each of the 11 financial topics can be found in Appendix 2.

Not only do students in liberal arts education have a desire to learn more about financial literacy, they also have a need for it. We asked students what they thought the average interest paid on savings account in the United States is currently, and $70 \%$ of students answered incorrectly. Students were also asked about the frequency they engaged in seven different financial behaviors with responses supporting the need for education. For example only $32 \%$ of students admitting they keep track of their expenses on a regular basis.

The message is clear, liberal arts students have the interest, need, and desire to learn more about financial literacy. So what is the most effective way to teach about financial literacy in such a diverse group of students with various interests and abilities? From the students' perspective, 64\% suggested classroom instructions, 50\% liked the idea of one-on-one support, 34\% suggested computer based instruction or online videos, $38 \%$ suggested workshops, and $26 \%$ wanted a webpage. The student's two least favorable methods of teaching financial literacy were email blasts and newsletters.

Overall, the students need for a classroom environment or one on one support, with the additional online resources seems to be the most popular idea of how the students would like to learn. These findings seem to be in line with other research (Lyons, 2004; Mandell \& Klein, 2007; Goetz et al., 2011; "National," 2006) of strong interest by students in learning more about financial topics as well as support for a multi-faceted approach to education. Putting all of these resources together can ensure that many students would have an avenue to learn about important financial literacy topics that are necessary postgraduation. Since a large majority of students in liberal arts colleges are not business or finance oriented majors, they lack this type of education unless they take the liberty to learn about it on their own. Many 
students lack the resources and find themselves at a loss of where to start educating themselves on these topics, and this is where we can help!

\section{NEXT STEPS}

Fortunately, colleges and universities are becoming more aware of their unique opportunity to help prepare students to achieve a better financial future. As a result financial literacy initiatives are becoming more common as institutions strive to increase student retention and graduation rates and address rising student loan default rates. In addition by offering financial education programs colleges and universities are doing their part in contributing to the community and overall economy by preparing more informed citizens.

Next steps related to this project is to evaluate how to implement a program on the campus surveyed. A first step is to explore external vendors that provide the curriculum and often the instructors or training for the instructors and compare this to the option of developing a program in-house from scratch. The evaluation will include obtaining a list of services, cost of the services, and reviews of schools using the service of external vendors. After review and evaluation, this information will be shared with relevant areas on campus including Academic Affairs, Business Affairs and Financial Aid for input and feedback.

\section{REFERENCES}

Ergun, K. (2017). Financial behavior and financial literacy among university students. Research in Economics and Business: Central and Eastern Europe, 9(2), 77-94.

Federal Reserve Bank of New York. (n.d.). Get financially fit toolkit: A financial education toolkit for college campuses. Retrieved from http://www.newyorkfed.org/regional/Fin\%20Ed\%20Toolkit\%20for\%20College\%20Campuses.pd $\mathrm{f}$

Financial literacy in higher education: The most successful models and methods for gaining traction. (2014). COHEAO Financial Literacy Awareness White Paper. Retrieved from http://www.coheao.com/wp-content/uploads/2014/03/2014-COHEAO-Financial-LiteracyWhitepaper.pdf

Friedman, Z. (2018). Student loan debt statistics in 2018: A \$1.5 trillion crisis. Forbes. Retrieved from https://www.forbes.com/sites/zackfriedman/2018/06/13/student-loan-debt-statistics2018/\#6be2627310fa

Goetz, J.W., Cude, B., Nielsen, R., Chatterjee, S., \& Mimura, Y. (2011). College-based personal finance education: Student interest in three delivery methods. Journal of Financial Counseling and Planning, 22(1). Retrieved from https://ssrn.com/abstract=2061298

Grable, J. E., Law, R., \& Kaus, J. (2012). An overview of university financial education programs. In D. B. Durband \& S. L. Britt (Eds.), Student financial literacy: Campus-based program development, (pp. 9-26). New York: Springer

Lyons, A. C. (2004). A profile of financially at-risk college students. Journal of Consumer Affairs, 38(1), 56-80.

Lyons, A. C., \& Hunt, J. L. (2004). The credit practices and financial education needs of community college students. Financial Counseling and Planning, 14(1), 63-74.

Mandell, L., \& Klein, L. S. (2007). Motivation and financial literacy. Financial Services Review, 16, 106116.

McCormick, M. H. (2009). The effectiveness of youth financial education: A review of the literature. Journal of Financial Counseling and Planning, 20(1), 70-83.

Money Maters on Campus. (2014). How early financial attitudes, knowledge, and high school preparation influence financial decisions. EverFi.

Moore, R. (2004). Credit card knowledge, attitudes and practices of college students. Unpublished doctoral dissertation, Texas Tech University, Lubbock, TX 
National Endowment for Financial Education (NEFE). (2006). Closing the gap between knowledge and behavior: Turning education into action. Financial Counseling and Planning, 17(1), 73-90.

Nguyen, M. (2012). Degreeless in debt: What happens to borrowers who drop out. Washington, D.C.: Education Sector Retrieved from https:/www.google.com/search?q=Degreeless+in+debt+Education+Sector\&rlz=1C1CHBD_enU S797US797\&oq=Degreeless + in + debt+Education+Sector\&aqs=chrome.69i57.9568j0j7\&sourceid $=$ chrome \&ie $=$ UTF-8

Ross, T., Kena, G., Rathbun, A., KewalRamani A., Zhang, J., Kristapovich, P., \& Manning, E. (2012). Higher education: Gaps in access and persistence study (NCES2012-046). U.S. Department of Education, National Center for Education Statistics. Retrieved from http://nces.ed.gov/pub2012/2012046.pdf

Survey of the states: Economic \& personal finance education in our nation's schools. (2018). Council for Economic Education. Retrieved from https://www.councilforeconed.org/wpcontent/uploads/2018/02/2018-SOS-Layout-18.pdf

2017 U.S. Bank Student Financial Literacy Study. (2017). Retrieved from https://www.usbank.com/dam/images/newsroom/news/2017_US_Bank_Student_Financial_Litera cy_Study.pdf 


\section{APPENDIX 1}

Financial Literacy at Roanoke College

\section{Survey Questions:}

1) What is your academic status?
a. Freshman
b. Sophomore
c. Junior
d. Senior

2) Please rate your interest in increasing your financial knowledge

a. 1-5 Star rating

3) What topics would you be most interested in learning about? (Select all that apply)
a. Employment
b. Banking
c. Budgeting
d. Investing
e. Interest Rates
f. Student Loans
g. Personal Spending
h. Paying for College
i. Getting out of/Avoiding Debt
j. Saving
k. Managing money

4) How would you like personal financial learning opportunities delivered to you? (Select all that apply).
a. Classroom instruction
b. Newsletters
c. Computer-based instruction
d. Online Web Page
e. Workshops
f. One-on-one support
g. E-mail blasts
h. Online Videos 
5) Rate your financial behaviors based on the following statements.

(Never/Rarely/Sometimes/Always)
a. I put aside money for savings, future purchases, or emergencies
b. I pay my credit card bills on time each month
c. I prepare a monthly budget
d. I comparison-shop or buy things on sale
e. I keep track of my expenses on a regular basis
f. I know how much my student loans will add up to by my graduation date
g. I feel secure in my current financial situation.

6) How important is it that Roanoke College offer opportunities to learn about personal finances?
a. 1-5 Star rating

7) Select your highest monthly expense form the 5 categories below.
a. Food
b. Rent
c. Clothes
d. Alcohol and/or drugs
e. Other

8) What do you think the average interest paid on a savings account in the United States is?
a. $0-1 \%$
b. $1-3 \%$
c. $3-5 \%$
d. $5-7 \%$
e. $+7 \%$

9) How would you grade yourself on managing your money?
a. $\mathrm{A} / \mathrm{B} / \mathrm{C} / \mathrm{D} / \mathrm{F}$

10) What sounds most like your current financial situation?
a. I'm barely keeping up
b. I'm doing just fine 


\section{APPENDIX 2}

What Topics would you be most interested in learning about? (Select all that apply)

\begin{tabular}{|r|l|r|r|}
\hline \# & \multicolumn{1}{|c|}{ Answer } & Response & \multicolumn{1}{l|}{$\%$} \\
\hline 1 & Employment & 102 & $51.52 \%$ \\
\hline 2 & Investing & 120 & $60.61 \%$ \\
\hline & $\begin{array}{l}\text { Personal } \\
\text { Spending }\end{array}$ & 95 & $47.98 \%$ \\
\hline 4 & Saving & 116 & $58.59 \%$ \\
\hline 5 & Banking & 65 & $32.83 \%$ \\
\hline 6 & Interest Rates & 67 & $33.84 \%$ \\
\hline 7 & $\begin{array}{l}\text { Paying for } \\
\text { College }\end{array}$ & 75 & $37.88 \%$ \\
\hline 8 & $\begin{array}{l}\text { Managing } \\
\text { Money }\end{array}$ & 127 & $64.14 \%$ \\
\hline 9 & Budgeting & 119 & $60.10 \%$ \\
\hline 10 & Student Loans & 114 & $57.58 \%$ \\
\hline & Getting out & & \\
\hline 11 & of/Avoiding Debt & 112 & $56.57 \%$ \\
\hline
\end{tabular}

